\title{
THE IMPACT OF CAPITAL REVERSAL AND THE THRESHOLD OF CURRENT ACCOUNT DEFICIT ON RUPIAH
}

\author{
M. Noor Nugroho \\ Ibrahim \\ Tri Winarno \\ Meily Ika Permata'
}

\begin{abstract}
This paper studies the effects of foreign capital flows toward the exchange rate of rupiah both in total and across types of capital investment. This paper also analyzes the thresholds of current account deficit which significantly affect the rate of Rupiah. The estimation shows the capital outflow affect the rate of Rupiah to depreciate and is larger than the appreciation pressure of capital inflow (except when invested in Certificate of Bank Indonesia, SBI). Furthermore, the rate of Rupiah is more sensitive on government bond (SUN) than stock or SBI. The yield of this government bond largely affects the probability of the capital reversal. Related to the current account, the estimation shows that after exceeds the threshold of USD980 million monthly deficit orabout $2 \%$ of GDP, the exchange rate will depreciateby $12.7 \%$ (m-o-m) with the lag effect of 4 months.
\end{abstract}

Keywords: Capital flows, exchange rate, current account deficit, threshold.

JEL Classification: F31, F32

1 Authors are researcher on Economic Research Bureau, Directorate of Economy Research and Monetary Policy, Bank Indonesia. The views on this paper is solely of the auhtors and do not necessarily represent the views of Bank Indonesia. Corresponding author: nugroho@bi.go.id. 


\section{INTRODUCTION}

The activity of external sectors in the economy is generally reflected on the balance of payment dynamics, which later will affect the exchange rate of Rupiah. The main component of the balance of payment is the current account (CA) and capital account (Capital and Financial Account) and the change of foreign exchange reserve. When current account declines, it commonly related to the reduction of competitiveness and export activity, or the increase of import due to the strong domestic demands. After that, they then observe the other factors such as the economic development of the trading partner, the import content in production structure and in export products, etc. On the other hand, the decline of capital account is sometimes linked to the falling of foreign capital's value (sudden stop). In many countries, the dynamics of the foreign capital flow is often associated with the flow of investment portfolio considering the fact that this capital flow is more volatile than the other capital flows - direct investment and foreign debt. Unlike current account of which activity is more determined by fundamental and domestic factors, the dynamics of capital account depends more on investor's appetite (investor's portfolio). Furthermore, the dynamics of portfolio investment can directly affect the exchange rate ${ }^{2}$, therefore potentially cause instability in exchange rate and in domestic stock market.

In its development, the studies which investigate the external balance are getting to be more intensive following the Balance of Payment Crisis (BOP crisis), such as the crisis in Mexico (1992), Asia (1997/8) and Russia (1998). The sudden stop and capital reversal phenomenon which are linked to the deficit of CA (CA reversal) also occur in many countries. This phenomenon is usually marked with the movement of the capital outflow in a gigantic amount, while the capital inflow is limited. The imbalance of the capital outflow and inflow in one economy directly influences their exchange rate. When the capital outflow is a lot bigger than the capital inflow, the demands for foreign exchange will increase drastically and the exchange rate will depreciate. On the next stage, the sudden stop can influence the current transaction activities. Edwards (2004) observed 157 countries during the period of 1970-2001 and found 5.1\% of sudden stop events and $11.8 \%$ of CA reversals. Furthermore, he found from the total amount of 2.228 observations, $46.1 \%$ experienced both sudden stop and capital account reversal; showing that these two phenomena are related.

The sudden stop phenomenon which defined as the falling of the net inward flow of foreign capital in a gigantic amount occurred in Indonesia in after the 1997/98 crisis. The large of capital outflow increase the demand for foreign exchange much larger than the supply, which put large pressure for Rupiah to depreciate. In some periods of sudden stop, Bank Indonesia implemented a mix of policies which included foreign exchange intervention in considerable amount, reflected on the decline of the foreign exchange reserve.

2 The influence of CA activity on exchange rate is indirect. This is because the foreign exchange resulting from export activity will not directly enter the forex market. On the other hand, the needs of foreign exchange for import is not taken directly from foreign exchange market as well. Instead of buying forex right at import transaction, the importer can buy the forex periodically when the exchange rate is conducive for them. 
After the crises 2008, the global capital flew to the developing countries with high growth, supported by their strong domestic demand. However, the economic recovery process of developed countries was full of uncertainties and made the finance market condition to be susceptible to various negative sentiments. The finance market will fluctuate whenever the global risk indicators are getting worse. For recipient developing countries, the worsening global risk will make their foreign capital flow to be more volatile. The larger and the more volatile foreign capital flow will cause instability in foreign exchange and financial asset prices.

Indonesia is one of few developing countries survived from the 2008 crisis and recorded positive economic growth after the crisis. The foreign capital flow to Indonesia increased significantly. The capital inflow reached the highest number of more than USD26.6 million in 2010 (USD13.2 million of it was portfolio investment). The capital inflow pushes the appreciation of Rupiah for $12.5 \%$ to the average level of Rp9,080 per US dollar. However, the government bond price (Surat Utang Negara, SUN) increased as its yield declined from $10.07 \%$ in the end 2009 to the lowest level of about 7.01 in October 2010 and closed at the level of 7.83 in December 2010 (for 10 years SUN). The stock price index also increased from the level of 2,534 at the end of 2009 to the level of 3,703 by the end of 2010 .

Indonesia in general enjoyed a net inflow condition. However, in several point in 2010 Indonesia also experienced capital reversal, for example in May where the net outflow was significant and reached the number of USD4.8 billion, and USD865 million in November. The sudden reversal commonly occurs when there is negative sentiment in the developed countries who are still trying to get out of the crisis. The sudden reversal in Indonesia occur also on the second half of the 2011 with the net outflows of USD11.9 billion, and by mid of 2012 with USD2.9 billion. Those events significantly affected the rate of Rupiah.

On the other hand, slow recovery of US and EU from the crisis and the falling of Japan economy also influenced the decline of export activities in Indonesia. On the contrary, the strong domestic demand still pushed the import to grow, resulting current account to decline and even became deficit since quarter four 2011. Higher current account deficit affected the exchange rate significantly, and when current account deficit is relatively low it does not affect the exchange rate significantly.

Since the capital flow and current account activity can influence the movement of exchange rate, it is important to do a more comprehensive research on it. Moreover, the movement of the exchange rate will in turn affect the inflation which is the main task of Bank Indonesia. On the other hand foreign capital flow may affect the financial management and the financial system stability.

This paper measure the influence of foreign capital flow on the exchange rate, both in total and across investment types; SUN, SPN, SBI and stock. Furthermore, this paper also measure the influence of current account balance on the exchange rate and also test whether there is a current account balance threshold which significantly affecting the exchange rate of Rupiah. 
The next session of this paper outline the underlying theory and some previous studies. Section three discusses the data, the model and the method. Section four explain descriptive analysis, estimation result, and discussion, while section five outline the conclusion and close the presentation of this paper.

\section{THEORY}

The standard theory of open economy commonly refers to Mundell-Flemming model which combines the internal and the external balance. Internal balance is the equilibrium between IS and LM curve, where IS is the expenditure curve $(Y=C+I+G+N X)$ and $L M$ is the money rill curve $(\mathrm{M} / \mathrm{P})$. The external balance is shown by the balance of payment curve where the net position of the current account and the capital account in total is zero.

The internal equilibrium is the combination of the real sector and the financial sector. IS curve or the product market equilibrium is the accumulation of consumption, investment, and real interest rates deduced by inflation expectation equation. On the other hand, investment is the function of the income and the nominal interest rate. The net export is the function of the exchange rate, domestic income, and trading partner income. The financial (factor) market equilibrium is the function of income and real interest rate.

Consumption function is $C=C[Y-T, r-E(\pi)]$; investment function: $I=I\left[i-E(\pi), Y_{-1}\right]$; net export function: $N X=N X\left(e, Y, Y^{*}\right)$; and money market that represent the financial market is $M / P=f(Y, r)$; whereas the government expenditure is an autonomous factor $(G=G)$.

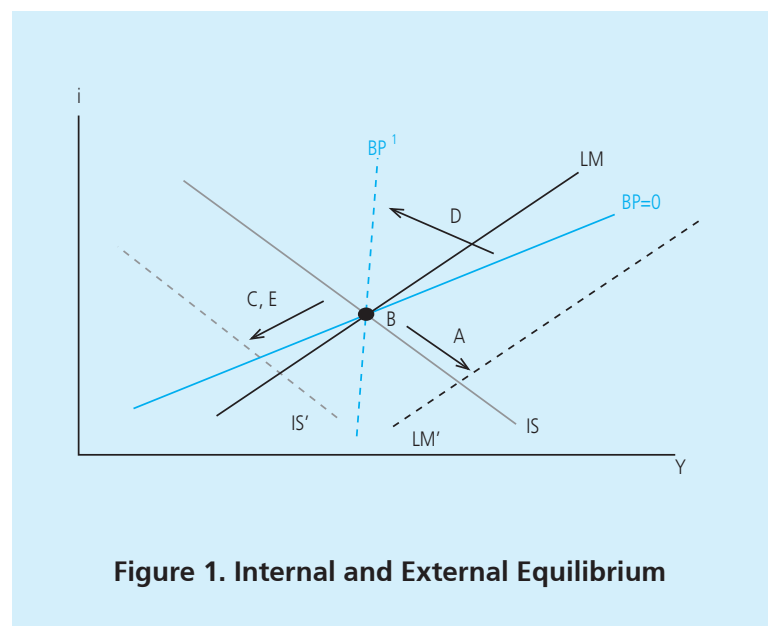

The internal and external equilibrium is shown by point $B$ on Figure 1 above which is the intersection of IS curve, LM and BOP $=0$ curve. The central bank policy to add the active circulation will shift LM to LM'. Moreover, due to the capital inflow phenomenon, the capital 
inflow to developing countries causes domestic currency demand to increase also. The result is in point $A$, where the interest rate is lower and the acquired output is bigger. Some policies which can be done are when the inflow is decentralised with the accumulation of reserve, it causes point $A$ to move back to point $B$. This will give implication to the longer capital inflow period due to the higher interest rate. The second policy which is possible to be done is when the central bank allows the entrance of capital and does not do sterilization so there is an appresiation on exchange rate. This will cause the decline of competitiveness and export. It will then shift IS from IS to IS'. Other policy which can be done is to do sterilization by limiting the capital inflow. This causes the domestic efficiency to decline, so domestic investment requires bigger cost (higher exchange rate) compared to the foreign one which offers lower cost.

In relation with external equilibrium, the exchange rate in floating exchange rate regime is determined by the interaction between the supply and demand as the standard theory of supply and demand. Demand is the amount of goods or service which can be bought by the consumers in different price levels, where the higher the price, the fewer the amount of goods or service the consumers want to buy. On the contrary, the supply is the amount of goods or service which can be sold by the producers at various price levels. The spread between demand and the amount of goods or service offered by the sellers is proportional with the price: the higher the price, the more amounts of products offered by the sellers of the intended goods. The equilibrium between the supply and the demand where the transaction take place is what we call as a market.

The market is in the equilibrium condition when the interaction between the supply and demand exists, and produces one equilibrium price on certain supply and demand quantities. The foreign exchange market is another type of market where the traded commodity is foreign exchange such as US dollar, Euro, or Japan Yen. The interaction between the foreign exchange supply and demand which determine the foreign exchange rate is illustrated below.

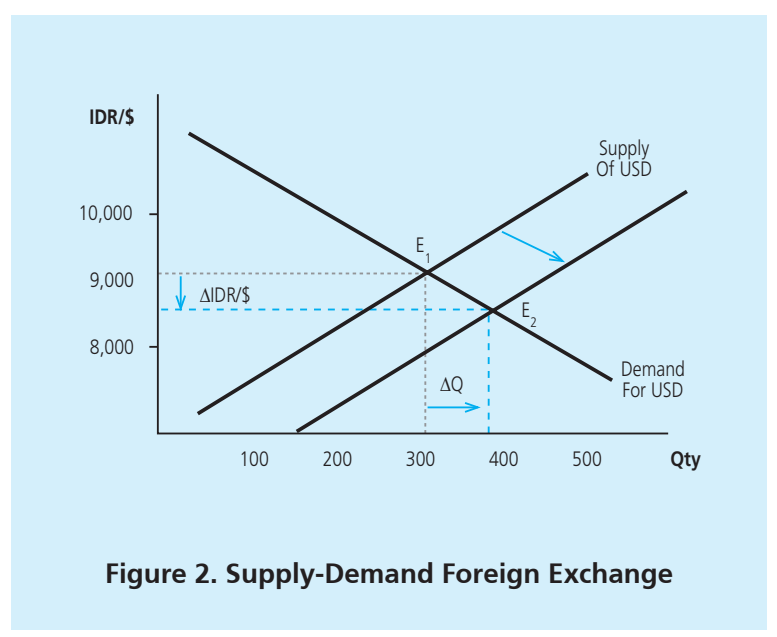


The negative correlation between the demand for US dollars with its price in Rupiah (IDR/\$) is represented by 'Demand for USD' curve. The higher the exchange rate (the increase of US dollar value), the lower the demand for US dollar will be. On the other hand, the correlation between the exchange rate and US dollar supply is reflected in positive slope line. Figure 5 shows the equilibrium of USD at the rate of Rp9,000/USD. Due to certain effect - for example when export increases, the supply of US dollar will shift to the right and create new equilibrium at E2 (Rp8,500/USD). In this case Rupiah appreciate or strengthen relative to USD.

Since the monetary crisis in the 1990s, economists have focused their attention on the global capital flow behavior. Some researches show that in globalization era, sudden capital reversal or sudden stop gives negative impacts on domestic economy. According to some economists (Dornbusch, Goldfajn and Valdes, 1995), sudden capital reversal also affects the Current Account (CA) reversal and expensive economic adjustment. Most of economic crises occurred in emerging market nowadays are marked by the sudden capital reversal (Calvo, 1998) which is then followed by the significant decline of output.

Edwards (2004) did a research using the panel data to answer the phenomenon on the impact of CA reversal toward the economic activity. They concluded that CA reversal will likely take place if the CA deficit reaches $4 \%$ of GDP. The CA reversal is also influenced by other factors such as foreign debt, domestic credit growth, and volatility of capital flow.

Sula (2008) used probit method and panel data to investigate the main factor causing the sudden capital reversal. It indicated that the main cause of sudden capital reversal is the high capital inflows in the previous period (around one to three years), and the composition of capital inflows which is dominated by non FDI.

Kaminsky, Lizondo, and Reinhart (1998) built and estimated empirical model on currency crisis by observing some variables with certain threshold and one of the variables are sudden capital outflows. They found the level of exchange reserve of less than three months import equivalent and a more than 5\% GDP current account deficit will trigger the currency crisis. Meanwhile, Frankel and Rose (1996) developed a method to provide early signal for exchange rate crisis occurrence by using probit model for developing countries. They found that sudden stop capital inflows and foreign debt composition significantly lead to currency crisis.

Sachs, Tornell and Valasco (1996) used panel data of 1995 to analyze the occurrence of currency crisis which is known as 'tequila effect' after the Mexico crisis. The found the significant effect of the vulnerable banking system, the overvalued exchange rate, and the falling of national foreign exchange reserve.

Another research using independent variable with threshold was carried out by Kan and Senhaji (2001). They used panel data and found supporting inflation threshold for the economic growth was 1-3 percent for developed countries and 11-12 percent for developing ones. 
Related to trade balance, Stahn (2006) carried out research on German exports and imports both with European Union and outside European Union (particularly the United States) using error correction model (ECM). He used REER and total sales deflator as price competitiveness, and regional export as a proxy for the demand for German export. The result confirmed the significance of price and demand on affecting the Germany's export.

Chinn and Prasad (2003) analyzed determinant of current account in developed and developing countries during the period of 1971-1995. Particularly for developing countries, Chin and Prasad found that the surplus on government budget, the net foreign assets position, and the trade volatility are closely related to current account balance.

Calderon et.al (2000) investigated current account deficit in 44 developing countries during 1966 to 1995 . The study found three conclusions; first, the higher the economic growth of a developing country, the more likely that the occurrence of CA deficit to be higher; second, the higher the economic growth of a developed country the more likely that the CA deficit occurrence is lower; third, the higher the interest rate will result on the lower CA deficit happens; and fourth, the appreciation of the real exchange rate increases the CA deficit, and (v) the international interest rate which is slowly decreasing will lead to the rise of CA deficit.

On Indonesian case, Sahminan et.al (2009) carried out research on the determinant of Indonesian current account as well as its dynamics using annual data from 1993 until 2008. The consumption rate, the real exchange rate and investments are the factors which explain the CA fluctuation in Indonesia. Moreover, by implementing inter-temporal approach, the research also found that the CA fluctuation in Indonesia is optimum.

This paper attempts to contribute to the scientific literature which relates to the impacts of sudden capital reversal phenomenon and CA on the exchange rate of Rupiahin the period subsequent to the global financial crisis in 2008. The next session outline the data we use and empirical model we estimate.

\section{METHODOLOGY}

\subsection{Empirical Model}

By the law of demand, an increase (decrease) of the commodity price will decrease (increase) the demand for the commodity and on the other hand increase (decrease) the supply of the commodity. The foreign exchange market also follows this law. The increase of US dollar's price toward Rupiah (depreciation of Rupiah) will reduce the demand of US dollar, and on the other hand will elevate the supply; vice versa. The interaction of both can be formalized on the following reduced form equations: 
Foreign exchange supply:

$$
Q_{t}^{S}=a_{0}+a_{1} S_{t}+a_{2} X_{i t}+u_{t}
$$

Foreign exchange demand:

$$
Q_{t}^{D}=b_{0}-b_{1} S_{t}+b_{2} X_{i t}+v_{t}
$$

where $Q^{S}$ and $Q^{D}$ are the foreign exchange supply and demand; $S_{t}$ is the exchange rate (standard quotation of the domestic currency per US dollar); and $\mathrm{X}_{i t}$ is other explanatory variables.

The market equilibrium exist when $\mathrm{Q}_{\mathrm{t}}^{\mathrm{S}}=\mathrm{Q}_{\mathrm{t}}^{\mathrm{D}}$ at equilibrium price $\mathrm{S}_{\mathrm{t}}$. However, in forex market bank determines the buying and selling exchange rate therefore supply and demand of foreign exchange does not always in equilibrium $\left(Q_{t}^{S} \neq Q_{t}{ }_{t}\right)$. Those excess demand or supply will be absorbed by the bank. Since the bank tends to be risk averse and is limited on its net open position, then the excess within the market is minimized or limited. To suppress the excess, the bank can change the selling/buying exchange rate offered to their customers. In this condition, the market condition for the foreign exchange faced by the bank can be represented by the following reduced from equations [(1)-(2)]:

$$
Q_{t}^{S}-Q_{t}^{D}=a_{0}-b_{0}+\left(a_{1}+b_{1}\right) S_{t}+\left(a_{2}-b_{2}\right) X_{i}+u_{t}-v_{t}
$$

By isolating $S_{t}$ we can get:

$$
S_{t}=\frac{\left(b_{0}-a_{0}\right)}{\left(a_{1}+b_{1}\right)}-\frac{1}{\left(a_{1}+b_{1}\right)}\left(Q_{t}^{S}-Q_{t}^{D}\right)+\left(\frac{\left(a_{2}-b_{2}\right)}{\left(a_{1}+b_{1}\right)}\right) X_{i}+\left(v_{t}-u_{t}\right)
$$

and after simplifying the coefficients we have:

$$
S_{t}=c_{0}-c_{1}\left(Q_{t}^{S}-Q_{t}^{D}\right)+c_{2} X_{i t}+e_{t}
$$

The foreign exchange net supply $\left(Q_{t}^{S}-Q_{t}^{D}\right)$ - in an open economy - might come from the international trade transactions (export-import) and the capital flows among the countries. All of those transactions are recorded on Current Account(CA) and Capital and Financial Account (FA) in the balance of payment.

$$
S_{t}=c_{0}-c_{1} C A_{t}-c_{2} F A_{t}+c_{3} X_{i t}+e_{t}
$$


This paper will focus on the study of the impact of capital reversal to the exchange rate of Rupiah. This is the reason we use equation 6 - and FA is defined as the short term capital flow (hot money) ${ }^{3}$. With a few modifications, we can highlight some important parts below:

- The asymmetrical influence of capital inflows and capital outflows: FA is separated into outflows and inflows;

$$
S_{t}=c_{0}-c_{1} F A_{-} I N_{t}-c_{2} F A_{-} O U T_{t}+c_{3} X_{i t}+e_{t}
$$

- Reversal influence based on the foreign divestment in SUN: FA is separated into foreign investment/divestment in SUN and other capital flows;

$$
S_{t}=c_{0}-c_{1} S U N_{t}-c_{2}\left(F A_{t}-S U N_{t}\right)+c_{3} X_{i t}+e_{t}
$$

- Reversal influence based on the foreign divestment on the stock: FA will be divided into foreign investment/divestment on the stock and other capital flows;

$$
S_{t}=c_{0}-c_{1} \text { Stock }_{t}-c_{2}\left(F A_{t}-\text { Stock }_{t}\right)+c_{3} X_{i t}+e_{t}
$$

- Reversal influence based on the foreign divestment on the stock: FA will be divided into foreign investment/divestment on SBI and other capital flows:

$$
S_{t}=c_{0}-c_{1} S B I_{t}-c_{2}\left(F A_{t}-S B I_{t}\right)+c_{4} X_{i t}+e_{t}
$$

- The reversal influence originated from foreign divestment on stock: FA will be divided into foreign investment and divestment on SPN and other capital flows;

$$
S_{t}=c_{0}-c_{1} S P N_{t}-c_{2}\left(F A_{t}-S P N_{t}\right)+c_{4} X_{i t}+e_{t}
$$

On the model specified above, the foreign capital flows variables invested in SUN, stock, SBU and SPN will be estimated in three alternatives; first, the net flows or net (inflows minus outflows); second, in the form of gross inflows and outflows (divided into 2 variables); and three, in the form of gross outflows only. This method allows us to see specific influence of each investment type/outlets on capital reversal occurrence.

Instead of observing the influence of sudden capital reversal towards the exchange rate, equation 6 also observe the influence of CA activity towards exchange rate, particularly on the efforts to determine the deficit of CA threshold which significantly trigger the occurrence of exchange rate depreciation.

3 The short term capital flow includes foreign investment on SUN, stock, Certificate of Bank Indonesia or SBI, and also some portion of foreign debt (assumed to be $50 \%$ ). 
To complete this research, we will estimate the probabilities of the sudden stop occurrence which is influenced by the push (foreign) and pull factors (domestic).

$$
\text { Reversal }_{t}=\Phi\left[c_{0}+c_{1} D J I A_{t}+c_{2} I H S G_{t}+c_{3} S U N_{\text {yield }}+c_{4} V_{I X}+e_{t}\right.
$$

Where $\Phi$ a is the normal cumulative distribution function; $D J A$ is the stock price index in the US; IHSG is the composite stock price index in Indonesia; $S U N_{\text {yield }}$ is the return of investments in SUN; and VIX is the volatility index which reflects the risk factor. DJIA and VIX represent the push factors, whereas IHSG and SUN $N_{\text {yield }}$ represent the pull factors.

\subsection{Estimation Technique}

This paper estimate the threshold of current account (CA) when it starts significantly affects the rate of Rupiah against USD. To find the threshold, we use non-linear model approach threshold autoregressive (TAR).

TAR is a regime-switching model which enables a variable to behave differently. Generally, the amount of threshold is often unknown and must be estimated al together with the other parameters. TAR model also accommodates the possibility that the length of the adjustment process for the regime to change after certain period, $d$. The value of $d$ is usually recognized as delay parameter.

Enders (2004) ${ }^{4}$ and Chan (1993) give the guidance to gain super consistent threshold value. Some of required conditions are:

1. Threshold should be placed within the range of observation period.

2. Estimate TAR model with different threshold levels and store the sum of squared residuals (SSR), then choose the smallest SSR. Another criteria to choose the best model is using smallest Akaike Information Criterion (AIC) and Schwarz Bayesian Criteria (SBC).

We apply the following threshold autoregressive (TAR) model:

$$
\begin{aligned}
\Delta e_{t}=\left(\alpha_{0}+\right. & \left.\sum_{i=0}^{k} \alpha_{1 i} L C A_{t-i}\right)\left(1-I_{t-d}\right)+\left(\beta_{0}+\sum_{i=0}^{k} \beta_{1 i} L C A_{t-i}\right)\left(I_{t-d}\right) \\
& +\sum_{i=0}^{l} \gamma_{i} \Delta I R D_{t-i}+\sum_{i=0}^{m} \delta_{i} \Delta R I S K_{t-i}+\sum_{i=1}^{n} \theta_{i} \Delta e_{t-i}+u_{t}
\end{aligned}
$$

4 Walter Enders. 2004. Applied Econometric Time Series. Wiley. 
which represent:

$$
\begin{aligned}
\Delta e_{t}= & \left(\alpha_{0}+\sum_{i=0}^{k} \alpha_{1 i} L C A_{t-i}+\sum_{i=0}^{l} \gamma_{i} \Delta I R D_{t-i}+\sum_{i=0}^{m} \delta_{i} \Delta R I S K_{t-i}+\sum_{i=1}^{n} \theta_{i} \Delta e_{t-i}+u_{t}\right) j i k a I_{t-d}<\gamma \\
& \left(\beta_{0}+\sum_{i=0}^{k} \beta_{1 i} L C A_{t-i}+\sum_{i=0}^{l} \gamma_{i} \Delta I R D_{t-i}+\sum_{i=0}^{m} \delta_{i} \Delta R I S K_{t-i}+\sum_{i=1}^{n} \theta_{i} \Delta e_{t-i}+u_{t}\right) j i k a I_{t-d} \geq \gamma
\end{aligned}
$$

The equation above is the application of TAR model on distributed lag model. On the above model, the change of exchange rate (depreciation/appreciation) is function of current account level (CA), change of interest rate differential, the global risk movement, and the adaptive expectation on exchange rate. The time lag from the independent variable is represented by $i$, where as the time lag from threshold variable is represented by $d$. Variable $/$ is the dummy variable, where $I_{t-d}=0$ when CA level is smaller than the threshold $\gamma$, and $I_{t-d}=1$ when CA level is equal or larger than the threshold $\gamma$.

We use monthly data from January 2008 until June 2012. The data includes the nominal exchange rate in log change $(\Delta e)$; current account level (LCA); interest rate differential change $(\Delta \mathrm{RD})$; and the global risk change $(\Delta \mathrm{RISK})$.

\section{RESULT AND ANALYSIS}

\subsection{Descriptive Analysis}

\section{The Dynamics of Balance of Payment}

The Balance of Payment in Indonesia fluctuates dynamically. Prior to the 1998 crisis, its current account was more often deficit and after the crisis it recorded surplus (Figure 3). The dynamic represent the economic structure of this country. Any changes either structural in nature or temporary will influence CA.

Structural change usually evolves gradually in a relatively long period and mostly relates to the development of the domestic economy. On the other hand,the domestic changes which are temporary in nature usually affect the balance of payment quickly in shorter period. As small developing and open economy, for Indonesia, all changes in international markets (commodity price and world trade volume) can give significant and immediate impact on its domestic economy, including on its current account. Those external changes will be transmitted via trading network. 


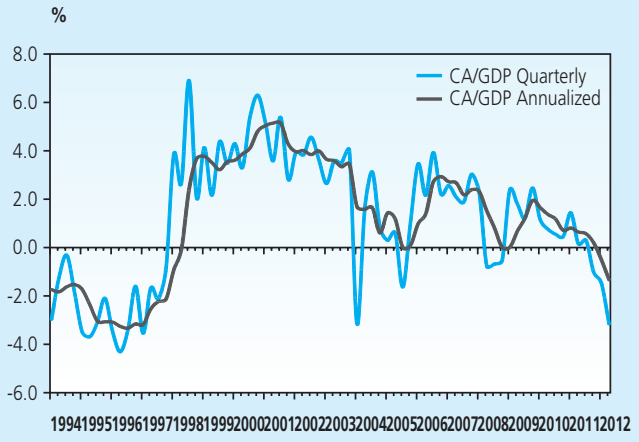

Figure 3.

The Development of Transaction (\% GDP)

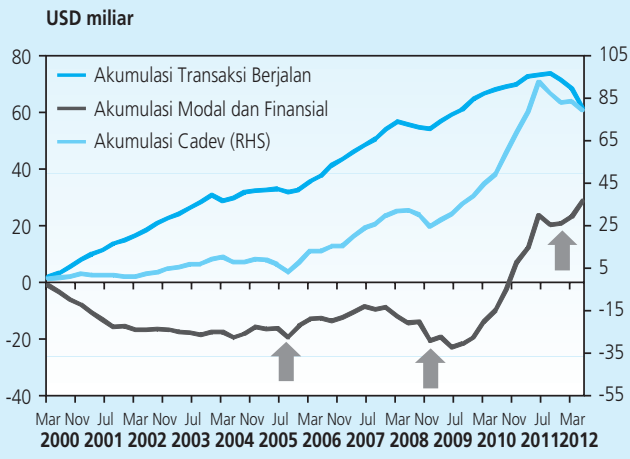

Figure 4.

The Development of the Main Indicator BOP

After 2000 or post the crisis, the management of macro policy was better. One of the most fundamental changes was the floating exchange rate regime which can detect the signal much faster when there is external side imbalance. During this regime however, the external indicator were also suffers from several shocks as reflected on balance of payment (BOP).

On domestic side, one source of economic instability is the change in national political system. Indonesian economy contains substantial politic uncertainties since the political reformation in 1998. The crisis of national leadership which is also characterized by the changing of president through the Special Session worries the foreign investors. The Standard and Poor (S\&P) rating reduced the investment rating in Indonesia in May 2001 and in November 2001. The international geopolitics particularly the event of September 11, 2001 affected the domestic economy and negative reaction for foreign investors within this country. The strings of political and economic instability affected the economic recovery process until 2002.

The period where the external equilibrium in Indonesia run relatively normal without significant political fluctuation and disturbances is the period after 2002. Statistic and BOP data also showed improvement relative to before 2000. Consequently, the external equilibrium fluctuation is mainly originated from external factor, hence relatively easy to compare. In general there are three episodes of huge pressure on Indonesia balance of payment; they are in the year of 2005, 2008, and in 2012.

We recognized the fluctuation in 2005 as mini crisis, where Rupiah depreciate drastically to the level of Rp11,000 per USD. This is equivalent to a depreciation of 8,5\% annually, which is higher than in 2008. The main trigger of the fluctuation in 2005 was the increase of the world commodity price, especially crude oil. The Fed's responded by increasing his rate by $200 \mathrm{bps}$ and made the foreign investors to relocate their investment portfolio to United States. With the increase of the world crude oil price, the domestic fuel price also increased by more than $100 \%$ and triggered sharp rise of inflation. 
In 2008, the source of fluctuation also came from external factor, particularly the raise of commodity price and the subprime mortgage crisis in United States. In the last quarter of 2008, the Lehman Brothers collapse added the strings of crises in global financial market. The massive foreign capital outflow put a high pressure on exchange rate and depreciate Rupiah to Rp12,000 per USD.

The latest episode of external shock for Indonesian balance of payment was in 2012, and was mostly caused by the crisis in Europe, and the decline of China and India's economy. The decrease of non-oil and natural gas commodities and the current rise of the world crude oil price also played a role in lowering Indonesian trade as evident in first and second quarter of 2012.

These three episodes of high external pressure on Indonesia balance of payment above are well described on Figure 4. The accumulation of net capital and financial transactions also decline along with the depreciation of Rupiah.

\section{The Characteristics of Short Term Capital Flow in Indonesia}

The component of balance of payment can be divided into two big components; the current account balance (CA), and the capital and financial balance (KA). In general, the components of CA contributing surplus are trade balance and transfer, while service and income contribute deficit (see Figure 5). The roles of those four components are varied depending on the nominal value. Since $2000-2011$, the trade balance contributed most by $49 \%$, while transfer transaction only contributed $6 \%$. Income and services contributed $25 \%$ and $19 \%$ consecutively.

On service trade balance, Indonesia as most of developing countries has weak competitiveness within the service products. This is the reason for their services transaction to

USD Miliar

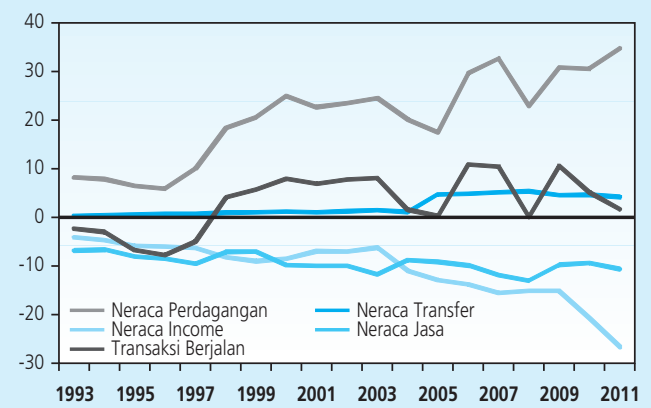

Figure 5.

The Development of CA Balance Component
USD MIliar

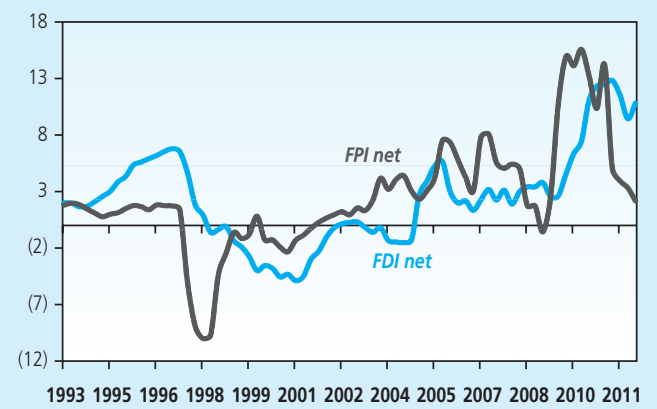

Figure 6.

The Development of Transaction Portfolio and PMA 
be deficit. The use of transportation and insurance services which is closely related to import activities causes the decline of CA which is relatively faster when there is a leap of import.

On the other hand, income transaction is related to the profit of foreign company on their investment; either in portfolio and direct investment (PMA). The raise of foreign interest to invest in 2010 and 2011 was one of the reason for the increase of deficit income.

On capital and financial balance (KA), the foreign capital flow is relatively limited and fluctuate. The accumulation of the capital flow was relatively stable from 2000 until 2008 (Figure 4). The significant rise occurred after 2009 along with the domestic economy recovery (see Figure 6). However, the role of the portfolio capital is still dominant. Since the instrument for foreign exchange transaction is still limited, and on the other hand the domestic foreign exchange market is shallow, then the short term negative sentiment can easily trigger the foreign capital flow, and then alter the Rupiah rate.

The global economic crisis in 2008 due to subprime mortgage problems in the US leaded foreign capital flow to the emerging countries. The crisis which then spread to the European Union and the world forced the developed countries to apply a quantitative easing and expansionary fiscal policy to save their economy. The abundant global liquidity flew to the emerging countries. However, due to the elevation of the global economic recovery uncertainties, this capital flow was very volatile.

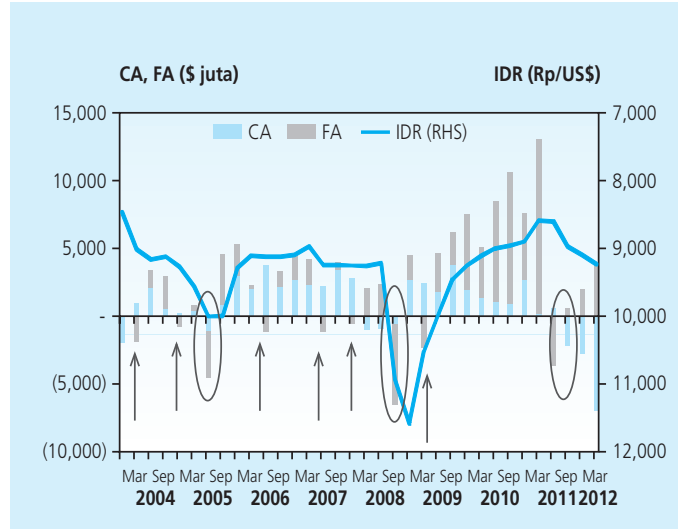

Figure 7.

CA and FA Balance

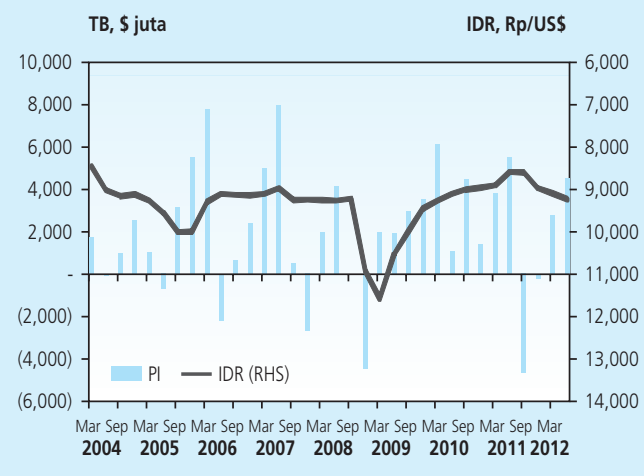

Figure 8.

Portfolio Investment

As we have witnessed, the foreign capital flow to Indonesia also tended to increase continuously, but most of them are short term capital in the form of portfolio investment. After the 2008 crisis, the capital flow raced along to Indonesia was recorded to amount of USD49.7 billion during third quarter 2009 until 2011 quarter three. USD29 billion or 58 percent of this inflow was portfolio investment (PI). The incoming flow of this capital pushed up the Rupiah 
financial asset price as reflected in the increase of capital stock index (Indeks Harga Saham Gabungan, IHSG) and the decline yield of government bond (Surat Utang Negara, SUN).

Among several studies on the foreign capital flow to Indonesia after the 2008 global crisis, Agung et.al (2011) confirmed the rise of foreign capital flow to Indonesia which is dominated by the short term fund (PI). The implication is that the foreign capital flow in Indonesia tends to be more volatile which is reflected by the rise of coefficient of variation in portfolio investment (PI). Similar pattern was found during the global crisis of 2008. This research comprehensively reveals the foreign capital flow to Indonesia both in the form of FDI, portfolio (FPI), as well as Other Investment (foreign debt). Portfolio investment flows directly affect the demand and supply of foreign exchange; hence the Rupiah rate.

Agung et.al (2011) further analyzed it through the investment outlet (SUN, stock and $\mathrm{SBI}$ ). The investment on SBI was the most volatile investment (temporary in nature or not persistent) and became more volatile subsequent to the 2008 crisis. Bank Indonesia responded by implementing minimum holding period on SBI for six months. The foreign capital flow in stock market was also volatile. The volatility on this type of investment tended to increase after the 2008 crisis. Capital flow invested on foreign bond (SUN) is different. Unlike SBI and stock, the foreign investments on SUN in fact became more persistent. It was parallel with the economic activity in Indonesia which still runs well - including the stable fiscal deficit.

Furthermore, Agung et.al (2011) also showed that the foreign capital to Indonesia was relatively short investment (1-2 months). Nugroho (2010) also shown that the foreign capital duration invested in Indonesia is relatively short (one month). This is in accordance with the fact that most of the foreign agent transacting in foreign exchange market are traders, and not truly investor. They do the foreign exchange buying and selling in the short term period to gain profit.

Another significant characteristic from the foreign capital flow is its asymmetrical impacts on the exchange rate. Agung et.al (2011) proves that the capital outflow has bigger influence on the exchange rate of Rupiah and has longer duration compared to the impacts of capital inflow. Sugeng et.al (2009) also proves that the capital outflows influence (the rise of foreign exchange demand or the decline of foreign exchange supply from the foreign agent) has bigger impacts on the depreciation of Rupiah compared to the capital inflows impact on Rupiah appreciation. Sugeng (2009) also proves that the impacts of foreign exchange transaction which is carried out by the foreign agent has more significant impacts on the exchange rate of Rupiah than the impacts of foreign exchange transaction by domestic agents.

This section has briefly described the actual condition of the market, the agent behavior and the external condition of Indonesian economy. The next section will confront this reality with the result of the estimated model. 


\subsection{Estimation Result}

The empirical test result (Table 1) shows that the capital flow- both the inflows and the outflows- significantly affects the rate of Rupiah. However, the impact is asymmetrical where the capital outflows give bigger impacts than the capital inflows. The estimation shows that whenever the capital flow out - especially capital reversal - in about USD100 million, the Rupiah will depreciate by Rp3,2 on the same day. The Rupiah depreciation due to this capital outflow will continue to the next day, though with smaller depreciation; see Figure 9 below. The accumulative impact of USD100 million capital outflow will depreciate Rupiah by Rp16 in about 15 days. On the other hand, the impact of same amount of capital inflow will appreciate Rupiah by Rp3, with a three days lag.

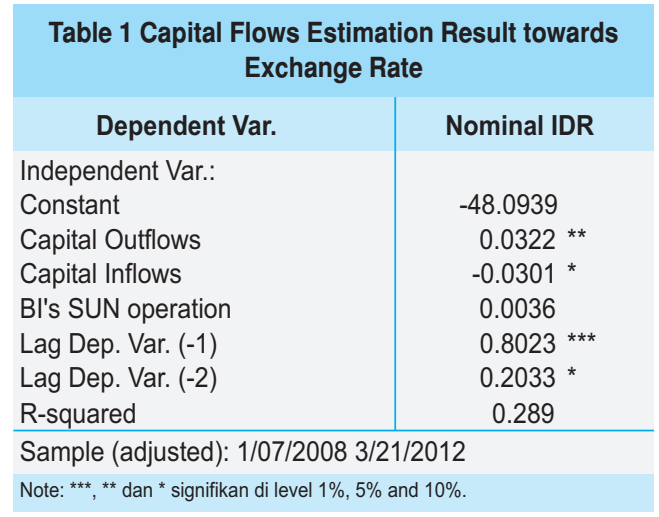

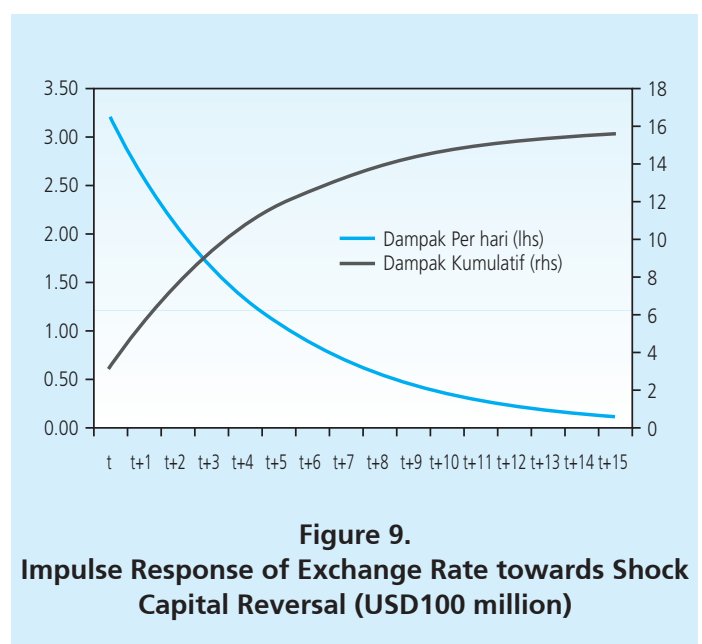

The effect of monetary operation by central bank using government bond (SUN) is in accordance with the theory. A liquidity expansion when Bank Indonesia increases their buy on SUN will depreciate Rupiah rate. However, this impact is not statistically significant. On the other hand, the exchange rate level in the previous period largely determines the current Rupiah rate.

The capital inflow in Indonesia in the form of portfolio investment is generally on SUN (the long term government bond, up to 30 years), the SPN (short term government Treasury bill), $\mathrm{SBI}$ and stock. A more intensive research shows that the effect of capital inflow differs across those types of portfolio investment. Generally, the foreign capital flow - either in the form of gross inflow, gross outflow, or net flows - invested in all investment types above (except stock), significantly affect the rate of Rupiah. Capital inflows lead the Rupiahto appreciate, while capital outflow lead Rupiahto depreciate, whereas net inflows lead Rupiah appreciation. 
Based on our estimation (see Table 2), the foreign capital flow in SPN gives the largest impacts on Rupiah's rate. The impact of foreign capital flow on SUN is the second largest, followed by stock, and finally SBI. Interestingly, the estimation result indicates the asymmetrical influence between the inflow and the capital outflow. The estimated coefficient for the capital outflow is larger than the inflow one, except for foreign investment in SBI. The next section will describe the effect of capital flow on Rupiah rate for each types of investment.

\begin{tabular}{|c|c|c|c|c|c|}
\hline \multicolumn{6}{|c|}{$\begin{array}{c}\text { Table } 2 \text { The Comparison of the Influence of Foreign Capital Flow on the Investment } \\
\text { Outlets toward Rupiah Exchang Rate }\end{array}$} \\
\hline Variabel & & SUN & Stock & SBI & SPN \\
\hline Net Capital Flows & & $-0.0559 * *$ & $-0.0480^{*}$ & $-0.0289^{* *}$ & $-0.1524^{* * *}$ \\
\hline Capital Inflows & & $-0.0705^{*}$ & -0.0554 & $-0.0424^{* *}$ & $0.2135^{* x}$ \\
\hline Capital Outflows & & $0.1295^{\star *}$ & $0.1101^{* *}$ & $0.0359^{* *}$ & $0.2529^{\star \star}$ \\
\hline \multirow[t]{3}{*}{ Net Capital Flows } & Model 1 & $-0.0180^{* *}$ & $-0.0531^{* * *}$ & $-0.0287^{*}$ & $-0.0212^{* \star}$ \\
\hline & Model 2 & $-0.0290^{\star * *}$ & $-0.0495^{\star \star *}$ & $-0.0286^{* *}$ & $-0.0176^{*}$ \\
\hline & Model 3 & $-0.0266^{\star \star *}$ & $-0.0304^{* * *}$ & $-0.0364^{* *}$ & $-0.0223^{* *}$ \\
\hline
\end{tabular}

\section{The Impact of Investment Flows on SUN toward Exchange Rate}

Foreign capital flow placed in SUN significantly affect the movement of Rupiah rate, either we measure it as capital inflow, outflow, or net capital flow. Its affect is proven to be asymmetrical. A USD100 capital outflow will depreciate Rupiah by Rp13 based on the estimation using the equation 2. A slightly different of Rp14 is estimated using equation 3. On the other hand, the same amount of capital inflow will appreciate Rupiah rate by Rp7.

Table 3

The Estimation Result on the Effect of Foreign Capital Flow on SUN toward Exchange Rate

\begin{tabular}{|c|c|c|c|}
\hline Dependent Var. & Nominal IDR & Nominal IDR & Nominal IDR \\
\hline \multicolumn{4}{|l|}{ Independent Var:: } \\
\hline Constant & -42.7112 & -49.2248 & -54.6954 \\
\hline Net Capital Flows - SUN & $-0.0559 * *$ & & \\
\hline Capital Inflows - SUN & & $-0.0705 *$ & \\
\hline Capital Outflows - SUN & & $0.1295^{* *}$ & 0.1416 ** \\
\hline Net Capital Flows - Others & $-0.0180 * *$ & $-0.0290 * * *$ & $-0.0266 * * *$ \\
\hline Bl's SUN operation & 0.0034 & 0.0031 & 0.0031 \\
\hline Lag Dep. Var. (-1) & $0.7957^{* * *}$ & $0.7919 * * *$ & $0.7902 * * *$ \\
\hline Lag Dep. Var. (-2) & $0.2095 *$ & $0.2138^{* *}$ & $0.2159 * *$ \\
\hline R-squared & 0.9966 & 0.9968 & 0.9967 \\
\hline
\end{tabular}


When we use the net capital flow, we found smaller coefficient. An USD100 million net capital inflow placed on SUN will appreciate Rupiah by Rp1,8 - Rp2,9. Accordingly, the same amount of net capital outflow will lead Rupiah to depreciate by the same figures.

\section{The Impact of Investment Flows on the Stock towards Exchange Rate}

For stock investment, not all capital flow affects the Rupiah's rate. The net capital flow and capital outflow affected the exchange rate; however, the capital inflow does not. The outflow of capital from the stock investment to the amount of USD100 million will depreciate Rupiah by Rp11 - Rp12. Whereas the net capital inflow of the same amount will appreciate Rupiah by Rp4.8.

When we use the by net capital flow (inflow minus outflow), the estimated coefficient showed an USD100 million of net capital inflow will appreciate Rupiah by Rp3 - Rp5.3; and vice versa, same amount of net capital outflow will depreciate Rupiah also by Rp3 - Rp5.3.

\begin{tabular}{|c|c|c|c|}
\hline \multicolumn{4}{|c|}{$\begin{array}{c}\text { Table } 4 \\
\text { The Estimation Result of the Influence of Foreign Capital Flow on Stock toward Exchange Rate }\end{array}$} \\
\hline Dependent Var. & Nominal IDR & Nominal IDR & Nominal IDR \\
\hline \multicolumn{4}{|l|}{ Independent Var.: } \\
\hline Constant & -37.5825 & -44.8483 & -50.0494 \\
\hline Net Capital Flows - Saham & $-0.0480 *$ & & \\
\hline Capital Inflows - Saham & & -0.0554 & \\
\hline Capital Outflows - Saham & & $0.1101 * *$ & 0.1178 ** \\
\hline Net Capital Flows - Others & $-0.0531 * * *$ & $-0.0495^{* * *}$ & $-0.0304^{* * *}$ \\
\hline BI's SUN operation & 0.0032 & $0.0032 *$ & $0.0034 *$ \\
\hline Lag Dep. Var. (-1) & $0.8072^{* * *}$ & $0.8024^{* * *}$ & $0.7884^{* * *}$ \\
\hline Lag Dep. Var. (-2) & 0.1975 * & $0.2030^{* * *}$ & $0.2174 * * *$ \\
\hline R-squared & 0.9967 & 0.9968 & 0.9967 \\
\hline
\end{tabular}

Sample (adjusted): 12/19/2008 3/21/2012

Note: ${ }^{* * *},{ }^{* *}$ dan ${ }^{*}$ signifikan di level $1 \%, 5 \%$ dan $10 \%$.

\section{The Impact of Investment Flows on SBI toward Exchange Rate}

The foreign capital invested on SBI behaves slightly different with the other types of capital flow investment. The capital inflow invested on SBI affect the exchange rate much stronger than the capital outflow from SBI. A USD100 million capital inflow to SBI will appreciate Rupiah by Rp3.6, while the net foreign investment inflows on SBI by the same amount will encourage the appreciation of Rupiah by Rp2.9.

For this type of investment (SBI), we estimate three model variants. The result show the net flow of Other Investment (OI) also affected the exchange rate. The net capital inflow (out) 
to the amount of USD100 million will appreciate (depreciate) Rupiah by Rp3. The estimation result above also shows that the buying/selling operation of SUN by BI significantly affects the rate of Rupiah. If Bank Indonesia run monetary expansion by buying long term government bond (SUN) to the amount of Rp1,000 billion, then Rupiah will depreciate by Rp18.

\begin{tabular}{|c|c|c|c|}
\hline \multicolumn{4}{|c|}{$\begin{array}{l}\text { Table } 5 \\
\text { The Estimation Result on the Effect of Foreign Capital Flow on SBI toward Exchange Rate }\end{array}$} \\
\hline Dependent Var. & Nominal IDR & Nominal IDR & Nominal IDR \\
\hline \multicolumn{4}{|l|}{ Independent Var.: } \\
\hline Constant & 8.7738 & 4.5699 & 7.8794 \\
\hline Net Capital Flows - SBI & $-0.0289 * *$ & & \\
\hline Capital Inflows - SBI & & -0.0424 ** & \\
\hline Capital Outflows - SBI & & $0.0359 * *$ & $0.0338^{* *}$ \\
\hline Net Capital Flows - Others & $-0.0287 *$ & -0.0286 ** & -0.0264 ** \\
\hline BI's SUN operation & $0.0182^{* * *}$ & $0.0185^{* * *}$ & $0.0183^{* * *}$ \\
\hline Lag Dep. Var. $(-1)$ & $0.7800^{* * *}$ & 0.7795 *** & $0.7835^{* * *}$ \\
\hline Lag Dep. Var. (-2) & $0.2189 * *$ & 0.2199 ** & $0.2155^{* *}$ \\
\hline R-squared & 0.9722 & 0.9724 & 0.9722 \\
\hline \multicolumn{4}{|c|}{ Sample (adjusted): 11/25/2009 3/21/2012 } \\
\hline
\end{tabular}

\section{The Impact of Investment Flows on SPN toward Exchange Rate}

Similar to foreign capital invested on long term government bond (SUN), the foreign capital investment on Treasury Bill (SPN) also significantly affected the exchange rate of Rupiah. This is evident either when we evaluate the capital flow with inflow, outflow, or with net flow. An USD100 million capital outflow will depreciate Rupiah by Rp24 - Rp25. Contrary to this, the capital inflow with the same amount will only appreciate Rupiah by Rp21, showing an asymmetric effect. When we use the net value, the result show an USD100 million net capital inflow (out) on SPN will push the Rupiah to appreciate (depreciate) by Rp15.

The result of the estimation shows the impact of monetary expansion when Bank Indonesia buy SUN significantly affect the rate of Rupiah. The buying of SUN of Rp1,000 billion will push down Rupiah to depreciate by Rp19; vice versa. 


\section{Table 6}

The Estimation Result on the Influence of Foreign Capital Flow on SPN toward Exchange Rate

\begin{tabular}{|c|c|c|c|}
\hline Dependent Var. & Nominal IDR & Nominal IDR & Nominal IDR \\
\hline \multicolumn{4}{|l|}{ Independent Var.: } \\
\hline Constant & 2.2907 & -6.6035 & -26.5026 \\
\hline Net Capital Flows - SPN & $-0.1524 * * *$ & & \\
\hline Capital Inflows - SPN & & $-0.2135 * *$ & \\
\hline Capital Outflows - SPN & & $0.2529 * *$ & $0.2385 * *$ \\
\hline Net Capital Flows - Others & -0.0212 ** & -0.0176 * & $-0.0223 * *$ \\
\hline BI's SUN operation & $0.0187^{* * *}$ & $0.0186^{* * *}$ & $0.0187^{* * *}$ \\
\hline Lag Dep. Var. (-1) & $0.8107^{* * *}$ & $0.8333^{* * *}$ & $0.8236 * * *$ \\
\hline Lag Dep. Var. (-2) & 0.1889 ** & 0.1673 * & 0.1789 ** \\
\hline R-squared & 0.9734 & 0.9724 & 0.9726 \\
\hline
\end{tabular}

Sample (adjusted): 11/25/2009 3/21/2012

Note: ${ }^{* * *},{ }^{* *}$ dan ${ }^{*}$ signifikan di level $1 \%, 5 \%$ dan $10 \%$.

\section{The Impact of Current Account Activity on Exchange Rate}

We estimate several variants threshold estimation using TAR model, from which we choose the best threshold values on three models: AR-4, AR-5 and AR-6. The three models show the existence of CA deficit threshold, and if the CA deficit level exceed the threshold, then the effect on exchange rate becomes significant. On the contrary, when the level of CA deficit is under the threshold, then its impact will likely be tolerable for the market without causing any exchange rate fluctuation.

On model AR-4, the threshold of current account deficit is USD980 million, while in AR-5 model, the threshold is USD810 million. On the last model, AR-6, the current account deficit threshold is USD730 million.

The result of the estimation in January 2008 until June 2012 period shows the occurrence of CA threshold level to the amount of deficit of USD980 million (monthly) with 4 months lag. The impulse response figure shows that whenever the shock level of CA exceeds the threshold ( $\geq$ USD 980 million), the impact transmitted to the exchange rate with 4 months lag is $12.7 \%$ (m.o.m). The cumulative effect within 12 month year is the depreciation of Rupiah by $13 \%$ (figure 10 and 11). On the other hand, if the CA deficit does not exceed the threshold, the effect to the change of exchange rate is relatively small. The impulse response show the impact of USD500 million CA deficit (monthly), and the cumulative effect within 1 year is only 0,4\%. 


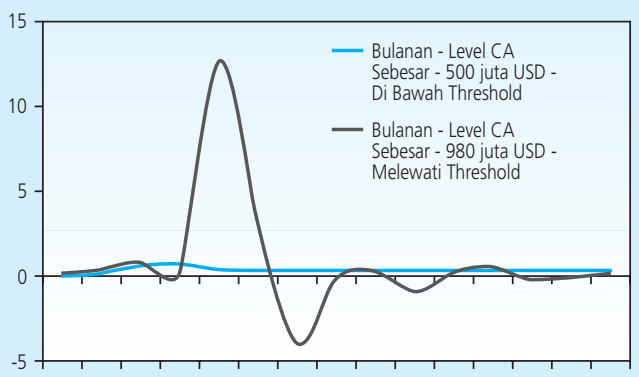

to $t+1 \quad t+2 \quad t+3 \quad t+4 \quad t+5 \quad t+6 \quad t+7 \quad t+8 \quad t+9 t+10 t+11 t+12 t+13 t+14$

Figure 10.

Impulse Response on the Decline of CA toward Exchange Rate (Deficit USD980 million)

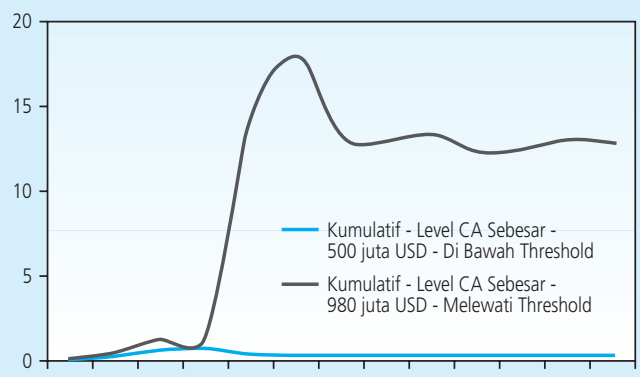

to $\quad t+1 \quad t+2 \quad t+3 \quad t+4 \quad t+5 \quad t+6 \quad t+7 \quad t+8 \quad t+9 \quad t+10 \quad t+11 \quad t+12$

Figure 11.

Impulse Response Cumulative on the Decline of CA toward Exchange Rate (Deficit USD980 million)

The second variant of the model AR-5 also cover the same period of January 2008 until June 2012. The impulse response shows that when deficit of CA exceed the threshold of USD810 million (monthly), the impact will be transmitted to the exchange rate with 4 months lag is depreciation of Rupiah by $32 \%$ (m.o.m). The accumulative impact after 1 year is the depreciation of Rupiah by $29 \%$ (graph 12 and 13). If the CA deficit level does not exceed the threshold, the effect of the change on exchange rate is also small. Cumulatively, the impulse response shows the shock of USD500 million CA deficit will depreciate Rupiah by $0.3 \%$ within one year.

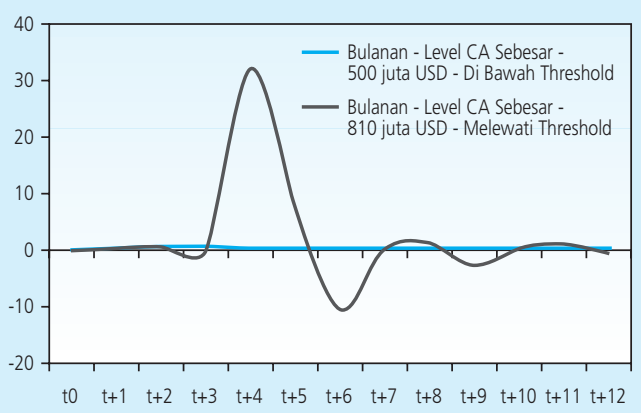

Figure 12.

Impulse Response on the Decline of CA toward Exchange Rate (Deficit USD810 million)

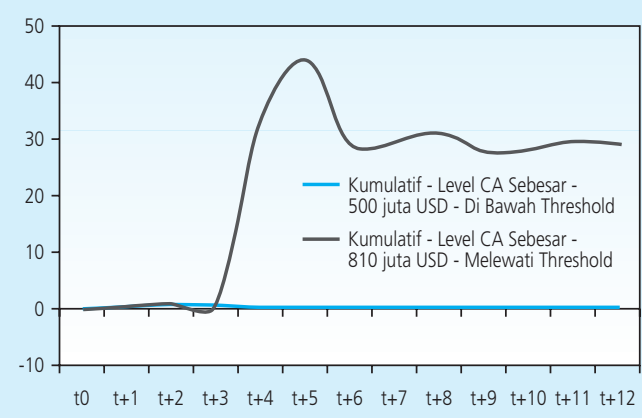

Figure 13.

Impulse Response Cumulative on the CA Decline toward Exchange Rate (Deficit USD810 million) 
On the last model, AR-6, the threshold of current account deficit is USD370 million. The impulse response shows that a shock of USD370 million CA shock deficit will depreciate Rupiah by $4.4 \%$ (m.o.m) with 4 months lag, and after one year, the cumulative effect is the depreciation of Rupiah by $3.3 \%$ (figure 14 and 15). When the shock is less than the threshold-say USD500 million, the cumulative impact is only $0.2 \%$ after one year.

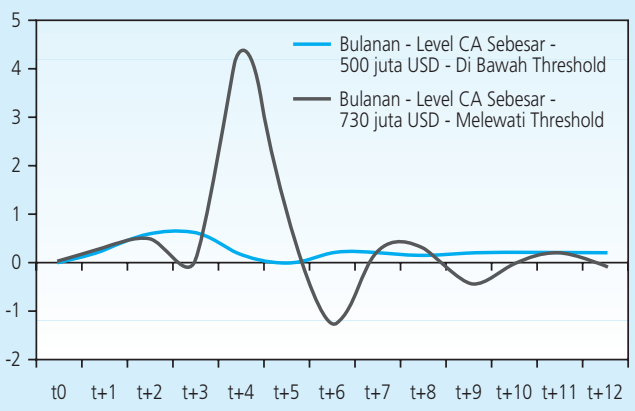

Figure 14.

Impulse Response to the Decline of CA toward Exchange Rate (Deficit USD730 million)

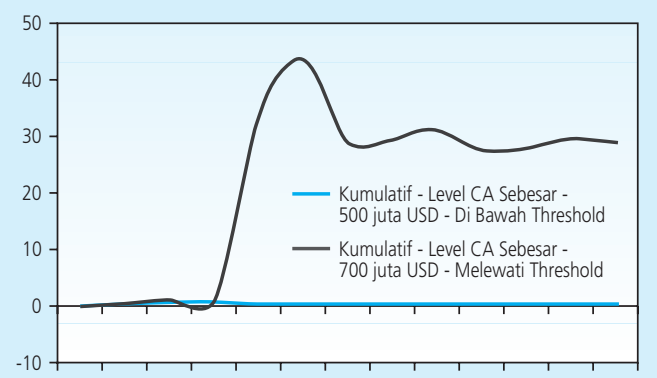

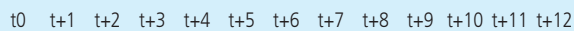

Figure 15.

Impulse Response Cumulative on the Decline of CA toward Exchange Rate (Deficit USD730 million)

\section{The Determinant and Probabilities of the Sudden Stop Occurrence}

To capture the capital reversal behavior, we apply probit model and this section outline its estimation result. Probit model capture the probability on capital reversal occurrence by observing the changes on some determinant factors such as the global stock price index (using Dow Jones Industrial Average index or DJIA), the global risk factor (VIX index), the stock price index in domestic market (IHSG), and the yield of the long term government bond (SUN).

We estimate three variants of econometrical model to explain the behavior of capital reversal. The first equation uses DJIA and yield SUN as explanatory variables. The estimation result shows the global stock price index negatively affect the probability of capital reversal occurrence. This means a global stock price index decrease will increase the probability of capital reversal.When the global stock price index decrease, investor would expect the domestic stock price will be affected hence they will withdraw their investment from Indonesia.

The yield of government bond (SUN) also negatively related to the probability of capital reversal; when the SUN yield decrease, the probability of capital reversal will increase. The yield is negatively related to the bond price. The decline of bond yield is associated with the price increase and leads the investor to gain profit by releasing their holding on SUN, particularly when the bond price is already over value. This is in line with the recognized behavior of foreign 
investors who attract more on short term profit. They buy the asset when its price is low and sell it right away when its price increases. The government bond (SUN) by foreign investors is identical with capital reversal.

On the second empirical model, we specify the yield of government bond (SUN) and the risk index (VIX) as explanatory variables. The influence of yield SUN toward capital reversal is relatively similar with the first model. On the other hand, the risk index also significantly affects toward the tendency of capital reversal occurrence. A worsening risk condition reflected by the increase of VIX index will raise the probability of capital reversal.

\begin{tabular}{|c|c|c|c|}
\hline \multicolumn{4}{|c|}{$\begin{array}{c}\text { Tabel } 7 \text { Estimation Result on the Sudden Reversal Probability Due to } \\
\text { the Investment Return and Risk Factor Change }\end{array}$} \\
\hline Dependent Var. & Prob. Cap. Reversal & Prob. Cap. Reversal & Prob. Cap. Reversal \\
\hline $\begin{array}{l}\text { Independent Var.: } \\
\text { Constant } \\
\text { Global Stock Price: DJIA } \\
\text { Yield SUN } \\
\text { IHSG } \\
\text { Risk Factor: VIX } \\
\text { Lag Dep. Var. (-1) } \\
\text { Lag Dep. Var. (-2) }\end{array}$ & $\begin{array}{l}2.0073^{* * *} \\
-0.0006^{* * *} \\
-0.1156^{*}\end{array}$ & $\begin{array}{l}-0.3944 \\
-0.1315^{* *} \\
0.0193^{* *} \\
0.6607^{* * *} \\
0.4164^{*} \\
\end{array}$ & $\begin{array}{l}0.0004^{* * *} \\
0.0238^{* * *} \\
0.6355^{* * *} \\
0.3841^{* * *}\end{array}$ \\
\hline R-squared & 0.1254 & 0.1110 & 0.1171 \\
\hline
\end{tabular}

The third model use the risk index (VIX) and domestic stock price index (Indeks Harga Saham Gabungan, IHSG) as explanatory. Both VIX index and IHSG index significantly affect the probability of capital reversal. An increase of risk index or stock price tends to increase the probability of capital reversal.

\section{CONCLUSION}

The foreign capital flow particularly the short term significantly affected the rate of Rupiah. The capital inflow will encourage the appreciation of Rupiah against USD and vice versa; however the marginal effect is asymmetric. In general the capital outflow depreciate Rupiah's rate more than when same amount of capital inflow appreciate Rupiah. An exception is for capital flow invested in Certificate of Bank Indonesia (SBI).

This paper analyze the behavior of capital flow across investment types, including long term government bond (SUN), Treasury Bill (SPN), stock, SBI, and Other Investment. We found that the exchange rate of Rupiah is relatively more sensitive toward foreign capital flow changes 
invested on SUN than stock or SBI. This is quite reasonable since the investors in the stock market can switch across stocks where the price movement provides them larger profit. Thus, the stock release by the foreign investors does not always imply capital reversal. A different case is for SUN, which price movement of each series tends to be linear, hence leaving the investors with only 2 options either invest in SUN or reverse their capital out (capital reversal).

On the other hand, the investment on SBI is relatively more limited and is related more to liquidity management. Moreover, SBI has a short span of maturity date (less than 1 year) so the investors automatically have to release SBI when they reach the maturity date, and any attempts to get it back in the primary and secondary market is constrained with limited supply. The exchange rate is also sensitive toward foreign capital flow on SPN. However, considering its limited volume, then its influence on the rate of Rupiah is also limited.

The foreign investors decision to invest in Indonesia is influenced by the level of investment return and risk. This paper found that the probability of capital reversal is significantly affected by global monetary assets (DJIA) and global risk factor (VIX), as well as domestic investment return (IHSG and SUN yield). The SUN yield significantly affects the probability of capital reversal, more than other explanatory variable, as far as the global risk is in good condition.

The fund flow originated from current account (CA) transaction is also significantly influence the rate of Rupiah. Moreover, the impact of worsening CA activity on Rupiah's rate will be larger when it exceeds certain threshold level. The estimation result shows that whenever the CA deficit exceed the deficit threshold of USD980 million (about $2 \%$ of GDP), the exchange rate will depreciate by $12.7 \%$ (m-o-m) with a 4 months lag.

Following the above findings, we derive some recommendations to keep the stability of Rupiah's rate; first, improving the monitoring on foreign investments especially on SUN and stocks. Second, increasing the monitoring of stock price index (IHSG), the SUN yield, and the global risk indicator, and use them to predict the capital reversal. Third, increase the performance of current account by any means to avoid its deficit exceeds the threshold. Fourth, to maintain the stability of Rupiah's rate when potential of capital reversal is detected, policy maker need to maintain sufficient foreign reserve to enable them intervene on forex market. 


\section{REFERENCES}

Agung, Juda, M. Noor Nugroho and Yanfitri (2011), "Arus Modal Jangka Pendek di Indonesia Pasca Krisis Global: Karakteristik, Prospek dan Respon Kebijakan", Bank Indonesia Working Paper, Juni 2011.

Berg, Andrew, and Pattillo Catherine (1999)" Are Currency Crisiss Predictable? A Test" IMF Economic Review, Jun 1999; 46,2.

Calderon, Cesar, Alberto Chong and Norman Loayza, 2000." Determinant of Current Account Deficit in Developing Countries," The World Bank Policy Research Working Paper, No. 2398.

Chinn, Menzie D., and Eswar S. Prasad. 2003." Medium-Term Determinants of Current Account in Industrial and Developing Countries: An Empirical Exploration" Journal of International Economics, Vol. 59, pp 47-76.

Calvo G (1998)" Capital Flows And Capital - Market Crises: The Simple Economics Of Sudden Stops" Journal of Applied Economics 1:35-54.

Edwards, Sebastian (2004), " Financial Opennes, Sudden Stops and Current Account Reversals" National Bureau of Economic Research, Working Paper 10277, January 2004.

Edwards, Sebastian (2005)," Capital Controls, Sudden Stops and Current Account Reversals" National Bureau of Economic Research, Working Paper 11170, 2005.

Frankel, Jeffrey A., and Andrew K. Rose, (1996)" Currency Crashes In Emerging Markets: An Empirical Treatment" Journal Of International Economics, Vol. 41 (nov), pp. 351-66.

Hansen, Bruce (1999), "Threshold Effects in Non-Dynamic Panels: Estimation, Testing, and Inference," Journal of Econometrics, Vol. 93, No. 2. pp. 345-68.

Hutchinson M, Noy I (2006)," Sudden Stops And The Mexican Wave: Currency Crisis, Capital Flows Reversal And Output Loss In Emerging Markets" Journal Of Development Economics 79(1): 225-249, 2006.

Kaminsky, Graciela, Saul Lizondo, and Carmen Reinhart, 1998" Leading Indicators Of Currency Crisis" Staff Papers, IMF, Vol. 45 (March) pp.1-48.

Khan, Mohsin S., and Senhaji Abdelhak S.2001" Threshold Effects In The Relationship Between Inflation And Growth", IMS Staff Papers, Vol. 48 No. 1. 
Nugroho, M. Noor (2010), "Perilaku Aliran Dana Jangka Pendek Asing dan Pengaruhnya pada Nilai Tukar Rupiah", Bank Indonesia Working Paper, Juni 2010.

Radelet S, Sachs J (1998) The East Asian financial crisis: diagnosis, remedies, prospects" Brooking Paper, economic Article 1:147-212.

Rodrik D, Velasco A (1999)" Short Term Capital Flows" National Bureau of Economic Research, Working Paper 7364, 1999.

Rudi Dornbusch, Ilan Goldfajn, dan Rodrigo Valdes. 1995"Currency Crisis And Collaps", Brookings Papers on Economic Activity, pp. 219-70.

Sachs, Jeffrey, Aaron Tornell, and Andres Velasco, 1996" Financial Crisis In Emerging Markets: The Lessons From 1995," Brooking Papers On Economic Activity:1, Brooking Institution, pp. 147-215.

Sahminan, Ibrahim, Yanfitri. 2009." Determinants and Sustainabality Indonesia's Current Account Balance". Working Paper No. WP/09/2009. Bank Indonesia.

Stahn Kerstin, 2006" Has The Impact Of Key Determinants Of German Exports Changed? Results From Estimations Of Germany's Intra Euro-Area And Extra Euro-Area Exports" Deutsche Bundesbank, Discussion Paper Series 1: Economic Studies No. 07/2006.

Sugeng, M. Noor Nugroho, Ibrahim and Yanfitri (2009), "Dampak Dinamika Penawaran dan Permintaan Valuta Asing Terhadap Nilai Tukar Rupiah dan Perekonomian", Bank Indonesia Working Paper, Juni 2009.

Sula, Ozan (2010)" Surges and Sudden Stops of Capital Flows to Emerging Markets", Open Economic Rev (2010) 21:589-605. 